\title{
WHY DO RETAIL CUSTOMERS HESITATE FOR SHOPPING GROCERY ONLINE?
}

\author{
Martin KLEPEK (i]*, Radka BAUEROVÁ(1) \\ Department of Business Economics and Management, School of Business Administration, Silesian \\ University in Opava, Opava, Czech Republic
}

Received 25 August 2020; accepted 16 November 2020

\begin{abstract}
Considering a relatively slow adoption of online grocery shopping in the vast majority of the world markets, the main objective of this study was to uncover any new reasons why customers hesitate to shop groceries online. Moreover, we were not looking for undiscovered discouraging reasons only but also intended to validate previously researched reasons in published studies. Thus, we have first used a systematic literature review to cover all relevant previous studies on online grocery non-buyers. Even though this process is time-consuming, it provides a coherent overview of the published material on the topic. Further, we designed a web-based survey of 670 respondents from the general internet population. The data in open-ended questions related to online grocery attitudes and opinions were analysed by the content analysis. 14 thematic units emerged from the process from which the majority confirmed previously researched negative attitudes toward online grocery shopping. Non-buyers prefer to see grocery in person before buying it, there is a distrust in e-tailers to choose the best and freshest grocery, non-buyers prefer personal contact with the seller and behave habitually. Moreover, they tend to shop offline also because of hedonic reasons and pleasure from the shopping experience. Novel reasons why people hesitate to shop online in this category were the time consumption where consumers perceived online shopping slow regarding order-delivery time gap and were reluctant to pay for the delivery service, to mention just a few. We conclude with a summary of our results and a handful of recommendation for e-tail companies.
\end{abstract}

Keywords: consumer behaviour, e-tail, e-commerce, marketing, online grocery shopping, online groceries, retail.

JEL Classification: L81, M31, L86.

\section{Introduction}

The development of technology influences to a large extent the possibilities of internet connection for a great number of people. With the ability to connect to the internet, individuals are allowed to move some of their activities into the digital environment. The shopping falls into this list of digitized activities bringing consumers new possibilities to increase conve-

${ }^{*}$ Corresponding author. E-mail: klepek@opf.slu.cz

Copyright $\odot 2020$ The Author(s). Published by Vilnius Gediminas Technical University

This is an Open Access article distributed under the terms of the Creative Commons Attribution License (http://creativecommons. org/licenses/by/4.0/), which permits unrestricted use, distribution, and reproduction in any medium, provided the original author and source are credited. 
nience, choice and accessibility of products. Online shopping has a huge potential for the future growth, which is accelerated by new technology development, clear legislation as well as the safety aspects of on-line shopping process (Simová \& Cinkánová, 2016). The new way of shopping was called e-commerce. The term quickly caught on in the professional circles and the general public. E-commerce is the online transaction of business, featuring the linked computer systems of the vendor, host, and buyer (Suchánek, 2010).

E-commerce is not only a term but also a fast-growing business. Global web sales neared $\$ 3$ trillion in 2018, increasing online's share of total retail sales to the north of $15 \%$ (Young, 2019). Internet purchase adoption across European countries has also been described. The highest shares were registered in Denmark (84\%), United Kingdom (83\%), Netherlands (80\%), Norway (79\%), Sweden (78\%), Germany (77\%) and Iceland (75\%), yet only 59\% of individuals purchase online in the Czechia (Eurostat, 2019a). Even though it could seem like there is a link between the level of economic development and e-commerce intensity, Kunešová and Eger (2017) proved the differences in development do not sufficiently explain the differences in the intensity of $\mathrm{B} 2 \mathrm{C}$ e-commerce.

Grocery purchases account for a large proportion of consumer spending (Ramus \& Nielsen, 2005). In the Czech Republic, grocery purchases are a significant item in the budget of most households (Šálková \& Hes, 2015). Over 90\% of households shop for groceries once a week or more (Kestenbaum, 2017). The rapid development of information technologies and their penetration among the population allows creating new business models based on these technologies. One of the new business models is online grocery shopping (OGS) where users buy groceries via the internet. The idea to sell groceries online was almost inevitable and both new and established brands have been exploring the field of online since the nineties. New brands mainly from the technological field had a head start with knowledge of coding, however miserable knowledge in retail business and consumer behaviour caused many to fail. In consequence, the most popular type of goods and services purchased online in the EU was clothes and sports goods (64\% of e-buyers), followed by travel and holiday accommodation (53\%) (Eurostat, 2019b).

Attempts to start online grocery sales have also attracted research teams and the number of articles on OGS has increased. Martín et al. (2019) observed the yearly increase of studies on OGS from 2000 to 2017 and also pointed that in the marketing area, many studies compared the advantages and disadvantages between e-commerce and physical retail. For instance, Degeratu et al. (2000) studied the importance of brand names, Danaher et al. (2004) compared brand loyalty of online and offline consumer, Andrews and Currim (2004) or Šarkovská and Chytková (2019) analysed differences in shopping behaviour and Huyghe et al. (2016) compared the channels with regards to healthy grocery shopping.

In 2018 the average online grocery shopping adoption in the EU28 countries was 17\% for individuals living in the cities, $14 \%$ for those living in towns and suburbs and $13 \%$ for rural areas (Eurostat, 2019b). The interesting fact is, that in rural areas the adoption more than doubled compared to the data from 2015 (6\%). Nevertheless, as mentioned by Hansen (2008) more than a decade ago, there is still a large group of customers resisting this way of buying. Also, Geuens et al. (2003) and Soopramanien (2011) warned about a massive number of consumers who are very sceptical about these new shopping alternatives. 
Interestingly, there is a huge satisfaction rate after an initial trial of OGS (Galvez-Cruz \& Renaud, 2006) and more experienced OGS shoppers tend to perceive OGS as less complex and therefore easier to use (Wang \& Somogyi, 2018; Verhoef \& Langerak, 2001). They also differ in perception, mainly in perceived compatibility, complexity compared to non-grocery or light OGS shoppers (Hansen, 2005a; Pechtl, 2003; Kozel et al., 2017). On the contrary, some surveys show that situational factors, such as having a baby or developing health problems, are triggers for starting to buy groceries online and also once these situational factors are gone consumer discontinues OGS as well (Hand et al., 2009). Thus, we infer that both external (situational factors) and internal (attitudes and perceptions) factors trigger the decisions to start to shop groceries online. Yet the internal factors in our view provide a higher possibility of continuation in this consumer behaviour. Moreover, they are far more likely to be influenced by marketing efforts compared to situational factors. Therefore, we focus our study mainly on consumers attitudes and perceptions.

The combination of using offline and online is called multichannel shopping. The large majority of online grocery shoppers are multichannel shoppers, thereby combining convenience advantages of online shopping with self-service advantages of offline stores (Campo \& Breugelmans, 2015). Moreover, OGS also varies by the delivery service level offered by a retailer. The services have two main distribution models. First, there is a click\&collect model, where an existing distribution network is used for collecting online preordered items. Second, the door to door delivery which allows customers to get the groceries delivered straight to home. In conclusion, even within the online grocery shopping business, there are two elementary modes of distribution. For the purpose of this article, we focus our attention on the second door-to-door delivery option since the click and collect model is not yet extensively available in the Czech Republic and Seitz et al. (2017) suggest the door to door delivery is also an option preferred among consumers.

Putting all the data in the context, we observe some interesting findings. Albeit the OGS efforts date back to the early nineties, it seems from the current adoption rates across the globe the concept is more of an evolution than revolution. But we should not be surprised. Similarly, offline retailers have spent decades fine-tuning their business model, promotions and consumer experience. Despite the initial enthusiasm, there is still much work to do to establish OGS as a relevant threat to the offline retail channel. From our perspective, there are still many limits and barriers for OGS adoption and consumer perceptions are one of them. Online retailers need to understand the drivers and barriers to online grocery shopping. Consequently, strategies, tactics, messaging and incentives can be promoted to encourage the online purchase and support the consumer habitual change further. We, therefore, address this issue by researching possible perceptions influencing non-buyers to hold negative opinions towards online grocery shopping.

The paper is structured as follows. First, we conducted a systematic literature review to answer the review question: What makes OGS non-buyers not to buy groceries online? Then, we analysed results and proposed primary data collection through a representative sample of Czech OGS non-buyers to fill the gap in the current research. The whole procedure is described in the second chapter. In the third chapter, we discuss results and last but not least we propose some further research possibilities and conclusions in the last part of the paper. Results could be used to improve communication strategies to make it a little easier to persuade people to buy groceries online. 


\section{Literature review and theoretical background}

While narrative literature review is important and somehow standard in social sciences, it can often include an element of selection bias (Uman, 2011). On the other hand, quantitative research synthesis or systematic literature review is considered the best practice across many disciplines (Tranfield et al., 2003; Potomková, 2005). Originating in medical sciences (Saunders et al., 2016), the systematic review was specifically developed to try to reduce the influence of the reviewer's own bias (White \& Schmidt, 2005). It is a highly standardized procedure allowing reproduction of a process because it provides transparency across almost all decisions (Fisch \& Block, 2018). In the systematic review, the researcher is required to set prespecified relevance and quality criteria for the selection of studies and to make such criteria transparent to readers (Denyer \& Tranfield, 2011). Reading a properly conducted systematic review is an efficient way to become familiar with the best available research evidence for a focused question (Garg et al., 2008).

All reviews, narrative and systematic alike, are retrospective, observational research studies and are therefore subject to systematic and random error. Accordingly, the quality of a review, and thus its worth, depends on the extent to which scientific review methods have been used to minimize error and bias. This is the key feature that distinguishes traditional narrative reviews from systematic reviews. If a review is prepared according to the preplanned steps, it is more likely to be systematic and to provide unbiased conclusions (Cook et al., 1997).

\subsection{Systematic literature review process}

Tranfield et al. (2013) describe 3 stages of a systematic review: (1) Planning the review, (2) conducting a review, (3) reporting and dissemination. In the first planning stage, we identified the need for a review. We have generally two reasons. First, there is a big difference between general e-commerce and OGS adoption rates. Hence, there could be possibly different reasons why people buy or do not buy. Second, to our knowledge, there is a majority of studies based on previous models adopting quantitative and deductive approaches asking existing regular online grocery shoppers. While these studies are of high importance, they represent only a small part of the retail consumer base opinions. The focus on online shoppers or those who have already adopted online shopping can inflate the predictions made concerning the future success of OGS (Geuens et al., 2003). Therefore, portraying a set of reasons why the vast majority of people do not adopt OGS will streamline the topic. Consequently, our review question is: What makes OGS non-buyers not to buy groceries online?

The question guides the review by defining which studies will be included, what the search strategy to identify the relevant primary studies should be adopted, and which data needs to be extracted from each study (Counsell, 1997). Thus, the keywords searched with "OR" operator were: online grocer ${ }^{\star}$, online retail, e-grocer* and e-tail. We used "*” sign to allow variations (grocery and groceries). The abstract, titles and article keywords were investigated by the query. Web of Science (WoS) and Scopus as today's two most prestigious scientific databases were used. The search resulted in 350 studies in Web of Science and 798 in Scopus. Only academic journal articles were accepted since these usually have higher qual- 
ity regarding the peer review process, sample sizes and overall rigour. Further articles only from the areas of economics, business, management, marketing, computer science, operations research were included in the list. This limitation led to a reduction in the number of studies as follows: $93 \mathrm{WoS}$ and 227 in Scopus.

The data was then exported into Microsoft excel and duplicities were deleted with the help of conditional formatting from the file resulting in the final 198 studies. Two authors formed a review panel and both reviewed titles from filtered studies. They classified articles into two categories: not relevant and relevant. The criteria for relevance were studies thematically focused on consumer research in the marketing area. All studies marked by both authors as not relevant were eliminated (113). Studies marked as irrelevant by one author only were subject to further inspection (abstract reading) and discussion (28). Majority of eliminated studies were from the field of logistics, information systems, environmental studies and management with no direct connection to consumer attitudes or perceptions towards OGS.

Furthermore, the authors read 68 abstracts to assess if the population subjected to the research were at least partially formed from OGS non-users. Again, the authors classified articles into two categories: not relevant and relevant. The criteria for relevance was the object of the research and these were consumers who do not shop groceries online. In conclusion, there were 9 studies left which matched all criteria and were subjected for a detailed analysis.

\subsection{Review synthesis}

For the general assessment of a final sample of studies, we have used Saunders et al. (2016) research onion framework. This layer system describes decisive steps in the research design. It ranges from research philosophy to data collection techniques and provides a valuable framework for understanding a body of scientific literature. First, our concern was the approach to the theory development. We wanted to research if the data was collected to verify or falsify existing theory (deduction) or to explore phenomenon (induction). Studies on the topic almost exclusively use a deductive approach (Table 1). Further, we control for methodological choices. Monomethod quantitative studies prevail in the sample. We were also interested in data collection techniques from which the web-based questionnaire was the most frequent. Apart from Saunders research onion, we have checked sample sizes and citations In Web of Science and Scopus databases to ensure research quality. Only two studies had less than 10 citations, however, due to relative novelty (Seitz et al., 2017; Driediger \& Bhatiasevi, 2019) we decided to keep these in our sample.

The popularity of theories such as the Theory of reasoned action (TRA), the Theory of planned behaviour (TPB) or the Technology acceptance model (TAM) generated several deductive studies using these for explaining the online grocery shopping behaviour (Hansen et al., 2004; Ramus \& Nielsen, 2005; Hansen, 2008; Driediger \& Bhatiasevi, 2019). Only one study from our final sample did not use the existing theoretical framework for solving research question thus seems inductive in its nature. This is not necessarily problem however recent trends in customer research encourage testing ideas from real-world phenomena (MacInnis et al., 2020). The one study we mentioned is Geuens et al. (2003). They approached the problem with the exploratory qualitative study with no previous focus set by any theoretical concept or framework. Further authors concluded that the Belgian consumers held a rather 
Table 1. Studies dealing with OGS non-buyers' perceptions and reasons not to buy groceries online (source: own research)

\begin{tabular}{|l|l|l|l|l|}
\hline Author(s) (year) & $\begin{array}{l}\text { Approach to theory } \\
\text { development }\end{array}$ & $\begin{array}{l}\text { Methodological } \\
\text { choice }\end{array}$ & \multicolumn{1}{|c|}{$\begin{array}{c}\text { Data } \\
\text { collection }\end{array}$} & Sample size \\
\hline $\begin{array}{l}\text { Hansen et al. } \\
\text { (2004) }\end{array}$ & Deduction & $\begin{array}{l}\text { Monomethod } \\
\text { quantitative }\end{array}$ & $\begin{array}{l}\text { Web based } \\
\text { questionnaire }\end{array}$ & $\mathrm{N}=1222+\mathrm{N}=1038$ \\
\hline $\begin{array}{l}\text { Ramus and } \\
\text { Nielsen (2005) }\end{array}$ & $\begin{array}{l}\text { Deduction and } \\
\text { Induction }\end{array}$ & $\begin{array}{l}\text { Monomethod } \\
\text { qualitative }\end{array}$ & Focus groups & 7 focus groups \\
\hline Hansen (2008) & Deduction & $\begin{array}{l}\text { Monomethod } \\
\text { quantitative }\end{array}$ & $\begin{array}{l}\text { Web based } \\
\text { questionnaire }\end{array}$ & $\mathrm{N}=1058$ \\
\hline Seitz et al. (2017) & Deduction & $\begin{array}{l}\text { Monomethod } \\
\text { quantitative }\end{array}$ & $\begin{array}{l}\text { Written } \\
\text { questionnaire }\end{array}$ & $\mathrm{N}=412$ \\
\hline $\begin{array}{l}\text { Driediger and } \\
\text { Bhatiasevi (2019) }\end{array}$ & Deduction & $\begin{array}{l}\text { Monomethod } \\
\text { quantitative }\end{array}$ & $\begin{array}{l}\text { Written } \\
\text { questionnaire }\end{array}$ & $\mathrm{N}=263$ \\
\hline Hansen (2005a) & Deduction & $\begin{array}{l}\text { Monomethod } \\
\text { quantitative }\end{array}$ & $\begin{array}{l}\text { Web based } \\
\text { questionnaire }\end{array}$ & $\mathrm{N}=784$ \\
\hline $\begin{array}{l}\text { Geuens et al. } \\
\text { (2003) }\end{array}$ & Induction & $\begin{array}{l}\text { Monomethod } \\
\text { qualitative }\end{array}$ & Focus groups & 8 focus groups \\
\hline Pechtl (2003) & Deduction & $\begin{array}{l}\text { Monomethod } \\
\text { quantitative }\end{array}$ & $\begin{array}{l}\text { Written } \\
\text { questionnaire }\end{array}$ & $\mathrm{N}=185$ \\
\hline Hansen (2005b) & Deduction & $\begin{array}{l}\text { Monomethod } \\
\text { quantitative }\end{array}$ & $\begin{array}{l}\text { Web based } \\
\text { questionnaire }\end{array}$ & $\mathrm{N}=1058$ \\
\hline
\end{tabular}

negative attitude towards online shopping, especially for fresh food products. The predictions made for the increase of online retailing for the next several years seemed far too optimistic for the authors as far as Belgian grocery shopping behaviour was concerned.

Even though Ramus a Nielsen (2005) used qualitative focus groups their approach seems to be deductive, as long as they underlined the research aim with the Theory of planned behaviour which guided themes captured in group discussions. In one part of the research, however, they asked open questions and adopted more of exploratory approach. Nonetheless, their findings are rich and interesting and offer a comparison of different consumer groups. Consumers not experienced with online grocery shopping felt that it was not convenient having to arrange for delivery at home at a suitable time and place. The inherent time lag between ordering and delivery when shopping online was mentioned as a barrier in situations of urgency. Impulse buying was discussed in nearly all researched customers groups. It seemed to be an important positive part of grocery shopping to a lot of consumers, and many participants believed that this element of shopping was sadly missing in online shopping which was regarded as much more planned and organized. Participants were also concerned with the freshness of the delivered products, and they expressed considerable uneasiness about the fact that they could not see, smell, hear, touch, feel, test or select the goods themselves. In the two groups of non-online shoppers there was a deep, spontaneously expressed distrust in the security of the payment systems when engaging in online shopping.

To answer our review question, we provide a summary with possible reasons why the majority of consumers do not adopt online grocery shopping in Table 2. 
Table 2. Studies dealing with OGS non-buyers' perceptions and reasons not to buy groceries online (source: own elaboration from reviewed studies)

\begin{tabular}{|c|c|}
\hline Author(s) (year) & Conclusions \\
\hline $\begin{array}{l}\text { Hansen et al. } \\
(2004)\end{array}$ & $\begin{array}{l}\text { Both theories (TRA and TPB) explain high proportion of the variation in future } \\
\text { online grocery behavioral intentions. However perceived behavioral control was } \\
\text { not determinant for online buying intention. }\end{array}$ \\
\hline $\begin{array}{l}\text { Ramus and } \\
\text { Nielsen (2005) }\end{array}$ & $\begin{array}{l}\text { Consumers miss out on the special, end-of-aisle bargains in the online grocery } \\
\text { shop. They also perceive increased risk of having to accept or return products } \\
\text { when they were in a bad condition or when products simply did not match the } \\
\text { expectations of the consumers. Also, selection and handling of perishables was a } \\
\text { major concern for consumers. Moreover, fun, enjoyment of shopping and social } \\
\text { aspect in offline store was missing element for many participants. There was } \\
\text { deep-rooted, distrust in the OGS systems of payment. }\end{array}$ \\
\hline Hansen (2008) & $\begin{array}{l}\text { Personal values affect consumers' attitude towards online grocery buying. } \\
\text { Consumers' attitude towards online grocery shopping was the most important } \\
\text { predictor of online grocery buying intentions. OGS non-buyers are to some } \\
\text { extent value-driven when forming their attitude towards online grocery } \\
\text { shopping. Perceived behavioral control was determinant for willingness to buy. }\end{array}$ \\
\hline Seitz et al. (2017) & $\begin{array}{l}\text { The main hindrance for most German consumers to shop for groceries online } \\
\text { is the lack of trust and confidence in the e-grocer and the digital marketplace. } \\
\text { Consumers do not feel the urgent need to shop for groceries online and are } \\
\text { happy with the status quo. }\end{array}$ \\
\hline $\begin{array}{l}\text { Driediger and } \\
\text { Bhatiasevi (2019) }\end{array}$ & $\begin{array}{l}\text { From consumer perspective, OGS firms need to offer competitive prices in } \\
\text { order to make online shopping appealing. Moreover, respondents declared that } \\
\text { they intent to use OGS when there is free home delivery. }\end{array}$ \\
\hline Hansen (2005a) & $\begin{array}{l}\text { Consumers consider online grocery shopping as an innovation that is different } \\
\text { from other grocery shopping channels. OGS buyers differ from the non-buyers } \\
\text { in perception of online grocery shopping characteristics. Perceived compatibility } \\
\text { was the primary discriminating construct. }\end{array}$ \\
\hline $\begin{array}{l}\text { Geuens et al. } \\
(2003)\end{array}$ & $\begin{array}{l}\text { Belgian consumers do not seem to expect or want dramatic changes or } \\
\text { revolutions in the retail business. They also hold a rather negative attitude } \\
\text { towards online shopping, especially for fresh food products. The predictions } \\
\text { made for the increase of online retailing for the next several years seem far too } \\
\text { optimistic as far as Belgian grocery shopping behavior is concerned. }\end{array}$ \\
\hline Pechtl (2003) & $\begin{array}{l}\text { The most impeding factors were the missing touch-and-feel experience, which } \\
\text { exhibited the highest absolute path coefficient, and the fear of losing track } \\
\text { while shopping. The latter problem arises if shopping on the Internet is not well } \\
\text { integrated into the existing shopping routines, signaling low complementarity. }\end{array}$ \\
\hline Hansen (2005b) & $\begin{array}{l}\text { Perceived relative advantage is positively related to consumers' attitude towards } \\
\text { online grocery buying, but perceived relative advantage is not related to future } \\
\text { online grocery buying intention. Consumers who already have carried out an } \\
\text { online purchase perceived relative advantage also directly affects the intention } \\
\text { to buy online again. }\end{array}$ \\
\hline
\end{tabular}

Most studies combined non-buyers and buyers, but few make a distinction when interpreting results for both groups. Results from Hansen (2005a, 2005b) suggest there is a difference within customers based on their experience with online grocery shopping. Even regular online buyers are dissimilar to only offline buyers in their perceptions of online grocery shopping. Therefore, our initial assumption that these two groups significantly differ and should be analysed separately persists. 
The deduction has been used almost exclusively in reviewed studies. While verifying theoretical models and precise statistical procedures to fit the data into a model is of high importance to understand consumer behaviour, these models usually explain only part of the variance in variables. Besides, from our analysis, it seems the studies built on these models dominate almost exclusively the field of OGS adoption. However, in most cases, they deal with intentions which is one of the recognized limitations of such studies. We, therefore, designed primary data collection to capture current reasons that limit non-buyers in online grocery shopping adoption. Our study differs in approach to theory development by having no existing theory as a research framework. We focused on open questions regarding online grocery shopping attitudes and opinions. We aimed to uncover any new reasons why customers hesitate to shop groceries online and to validate previously researched reasons in reviewed studies. Though it is not the attempt to true replication of the studies as it is described in the literature (Burman et al., 2010; Easley et al., 2000; Evanschitzky et al., 2007; Hubbard \& Armstrong, 1994), we believe the recurrence of the factors reinforces its credibility.

\section{Methods}

The survey method through the internet questionnaire was chosen for this research. Using this method, it was possible to obtain a suitable geographical dispersion of a large sample of respondents, which was important given the field of research that includes the Czech Republic as a whole. The questionnaire was used to collect attitudes and opinions through open question "Why do you not buy groceries online?". This type of question was chosen to provide unlimited answers, which contributed to a deeper understanding of the research problem. The content analysis identified thematic units explaining the main reasons for not buying food online. The frequency analysis also identified the frequency of individual thematic units to determine their importance in customer decisions. The last part of the research focuses on the comparison of acquired knowledge from the systematic literature review synthesis and content analysis.

\subsection{Content analysis}

This type of analysis was chosen based on the construction of a questionnaire in which an open question was used to get respondents to answer in their way. The content analysis can be used to find common ideas or themes in the answers to open-ended survey responses (Fink, 2009). This technique can be included in both qualitative research and quantitative research as it is an analytical technique that codes and categorises qualitative data to analyse them quantitatively (Saunders et al., 2016). The content analysis process generally consists of three steps: transformation and data selection, encoding the responses and visualization of the results. These steps are specifically described in the following paragraphs.

\section{Step 1: Transformation and data selection}

First, the data was examined in terms of the number of respondents' answers. The respondent was duplicated when multiple replies occurred. This procedure helps assign one code to a specific respondent to capture all his/her responses. Overall, 1,036 respondents' responses 
were collected from 762 respondents. Subsequently, a selection of irrelevant responses was made. In this section, the unanswered, illogical and non-specific responses were excluded from the further analysis. A total of 92 respondents were excluded from this selection. After this procedure, a total of 670 respondents with a total of 945 responses were further analysed.

\section{Step 2: Encoding the responses}

The second step in performing the content analysis is to assign specific codes to responses. In total, 14 thematic units were defined by the analysis. Subsequently, respondents' responses were categorized according to the similarity to the thematic units and were assigned the corresponding codes according to their classification. Labels for the thematic units were developed by the authors not corresponding to any previous categorization. The method of personal control has been selected to assign the answers to individual thematic units (assignment of codes). This method was chosen to correctly understand the meaning of the respondent's response and to ensure quality results. We did not use automated implementation of the content analysis since it is not recommended for the Czech language, owing to the impossibility of discerning irony or slang words (Tahal, 2015).

\section{Step 3: Visualization of the results}

To describe and evaluate the results of the examination was the last step in the process of the content analysis. The Frequencies analysis and a table collecting the most frequent responses in thematic units were used.

\subsection{Research sample and data analysis}

IPSOS online responding panel was used to obtain primary data. This company operates in the Czech Republic as an independent research agency. Respondents included in the research were residents of the Czech Republic. Their age was set up to 16 years and older to ensure a matching sample of customers purchasing grocery. The data set did not contain missing data due to non-acceptance of non-completed responses by the questionnaire system. The following table presents a deeper characteristic of the respondent sample.

As shown in Table 3, the sample is balanced in terms of gender representation of respondents, distribution by city size and cohesion regions. Only in the case of education and age groups and education is the sample slightly unbalanced. However, we were controlling for the representativeness and these deviation in distribution corresponds to the reality in the Czech society. These groups are respondents aged 16-24 (Czech Statistical Office [CSO], 2019a) and respondents without a secondary A-level education (CSO, 2019b).

\section{Results and discussion}

The results of the research and the discussion are divided into two parts, which results from the described research methods. The first part is focused on the presentation of thematic units and their most frequent respondents' answers. In this section there is also performed the frequency analysis to determine the degree of importance of individual thematic units 
Table 3. Sample characteristics (source: own research)

\begin{tabular}{|c|c|c|c|c|c|}
\hline \multicolumn{2}{|c|}{ Demographic characteristics } & \multicolumn{2}{|c|}{$\begin{array}{c}\text { In-store grocery } \\
\text { shoppers }(\mathrm{N}=670)\end{array}$} & \multicolumn{2}{|c|}{$\begin{array}{l}\text { Respondents excluded } \\
\text { from research }(\mathrm{N}=92)\end{array}$} \\
\hline & & Number & $\%$ & Number & $\%$ \\
\hline \multirow{2}{*}{ Gender } & Female & 320 & 47.8 & 36 & 39.1 \\
\hline & Male & 350 & 52.2 & 56 & 60.9 \\
\hline \multirow{5}{*}{ Age group } & $16--24$ years old & 81 & 12.1 & 9 & 9.8 \\
\hline & 25-34 years old & 132 & 19.7 & 18 & 19.6 \\
\hline & $35-44$ years old & 147 & 21.9 & 28 & 30.4 \\
\hline & $45-54$ years old & 140 & 20.9 & 15 & 16.3 \\
\hline & $55-65$ years old & 170 & 25.4 & 22 & 23.9 \\
\hline \multirow{4}{*}{ Education } & Basic & 240 & 35.8 & 26 & 28.3 \\
\hline & Secondary without A-level & 57 & 8.5 & 11 & 12.0 \\
\hline & Secondary with A-level & 264 & 39.4 & 39 & 42.4 \\
\hline & Tertiary & 109 & 16.3 & 16 & 17.4 \\
\hline \multirow{5}{*}{$\begin{array}{l}\text { Distribution } \\
\text { by city size }\end{array}$} & Up to 1,000 inhabitants & 100 & 14.9 & 19 & 20.7 \\
\hline & $1,001-5,000$ inhabitants & 146 & 21.8 & 17 & 18.5 \\
\hline & $5,001-20,000$ inhabitants & 128 & 19.1 & 14 & 15.2 \\
\hline & $20,001-100,000$ inhabitants & 154 & 23.0 & 16 & 17.4 \\
\hline & More than 100,001 inhabitants & 142 & 21.2 & 26 & 28.3 \\
\hline \multirow{8}{*}{$\begin{array}{l}\text { Cohesion } \\
\text { Regions } \\
\text { (NUTS 2) }\end{array}$} & Prague & 75 & 11.2 & 16 & 17.4 \\
\hline & Central Bohemia & 82 & 12.2 & 7 & 7.6 \\
\hline & Southwest & 77 & 11.5 & 9 & 9.8 \\
\hline & Northwest & 70 & 10.4 & 8 & 8.7 \\
\hline & Northeast & 95 & 14.2 & 10 & 10.9 \\
\hline & Southeast & 115 & 17.2 & 19 & 20.7 \\
\hline & Central Moravia & 79 & 11.8 & 13 & 14.1 \\
\hline & Moravian Region & 77 & 11.5 & 10 & 10.9 \\
\hline
\end{tabular}

for customers is their order from the most important unit to the least important. This part also includes results visualization for better readability and orientation of readers. The following part deals with the comparison of knowledge from secondary research and the results of primary research. This section also answers the research question defined in the section oriented to the systematic literature review synthesis.

\subsection{Results of a content analysis}

The respondents' responses were analysed according to the content of their open answers, which enabled identified 14 thematic units to help identifying why respondents do not buy grocery online. These thematic units are presented in Table 4, which also illustrates the most frequent answers of respondents that characterize the individual thematic units. 
Table 4. The most frequent responses in thematic units (source: own research)

\begin{tabular}{|c|c|}
\hline Thematic unit & Typical responses \\
\hline \multirow{4}{*}{$\begin{array}{l}\text { Prefer to see grocery in } \\
\text { person before buying it }\end{array}$} & Inability to inspect the goods physically. \\
\hline & The inability to sniff the goods. I need to see vegetables and fruits. \\
\hline & $\begin{array}{l}\text { The inability to test the taste of the goods before buying, the inability to } \\
\text { read the composition of the product. }\end{array}$ \\
\hline & $\begin{array}{l}\text { I can't check the grocery in advance - durability, packaging damage, } \\
\text { condition. }\end{array}$ \\
\hline \multirow{3}{*}{$\begin{array}{l}\text { Distrust e-merchants } \\
\text { to choose the best or } \\
\text { freshest grocery }\end{array}$} & I choose the freshest goods carefully. \\
\hline & Impossible to pick the best goods. \\
\hline & I know what I'm buying. \\
\hline \multirow{3}{*}{$\begin{array}{l}\text { The habit of shopping in } \\
\text { traditional stores }\end{array}$} & I am used to shopping in traditional stores. \\
\hline & I always buy food in a brick and mortar shop. \\
\hline & $\begin{array}{l}\text { All my life I go to the brick and mortar shop. I don't see a reason to } \\
\text { change it. }\end{array}$ \\
\hline \multirow{4}{*}{$\begin{array}{l}\text { Faster in-store grocery } \\
\text { shopping }\end{array}$} & I have goods immediately in traditional shops. \\
\hline & In traditional shops, it is without waiting for delivery. \\
\hline & Faster choice in a traditional shop. \\
\hline & $\begin{array}{l}\text { In traditional shops, I buy groceries when it comes to last-minute } \\
\text { purchases when it is necessary. }\end{array}$ \\
\hline \multirow{3}{*}{$\begin{array}{l}\text { Unwillingness to pay for } \\
\text { delivery }\end{array}$} & Paying the delivery fee for $200 \mathrm{CZK}$ purchase is uneconomical. \\
\hline & In traditional shops prices are free of shipping charges. \\
\hline & I have to pay for the delivery. \\
\hline \multirow{4}{*}{$\begin{array}{l}\text { Difficulties to return } \\
\text { purchases }\end{array}$} & Complicated complaint. \\
\hline & $\begin{array}{l}\text { When something is not suitable for me in a brick and mortar shop, I } \\
\text { simply do not take the goods and do not have to deal with the return } \\
\text { shipments. }\end{array}$ \\
\hline & Faster explanation of the claim in the traditional store. \\
\hline & The impossibility of personal complaint. \\
\hline \multirow{3}{*}{$\begin{array}{l}\text { Hedonic shopping in } \\
\text { traditional stores }\end{array}$} & I really enjoy going to traditional shops and choosing the items. \\
\hline & $\begin{array}{l}\text { I enjoy spending time walking in stores, looking for products and } \\
\text { looking at them. }\end{array}$ \\
\hline & I enjoy the atmosphere in traditional shops. \\
\hline \multirow{2}{*}{$\begin{array}{l}\text { Special offers in } \\
\text { traditional stores }\end{array}$} & Special offers in traditional brick and mortar shops. \\
\hline & Due to discounts in the traditional shops. \\
\hline \multirow{3}{*}{$\begin{array}{l}\text { Greater choice in } \\
\text { traditional stores }\end{array}$} & Better value for money choice in traditional stores. \\
\hline & More choices. \\
\hline & Better assortment offer. \\
\hline \multirow{3}{*}{$\begin{array}{l}\text { A sense of safety in } \\
\text { traditional stores }\end{array}$} & The certainty of a warranty. \\
\hline & Trust in traditional stores. \\
\hline & The credibility of the company. \\
\hline
\end{tabular}


End of Table 4

\begin{tabular}{|c|c|}
\hline Thematic unit & Typical responses \\
\hline \multirow{3}{*}{$\begin{array}{l}\text { Satisfaction in traditional } \\
\text { stores }\end{array}$} & Satisfaction with the offer of traditional shops. \\
\hline & It's more personal and enjoyable in traditional shops. \\
\hline & It suits me to shop in traditional stores. \\
\hline \multirow[t]{3}{*}{ Physical availability } & Shops, where we are used to shopping, do not have e-shops. \\
\hline & There is no online grocery delivery in my neighbourhood. \\
\hline & Grocery e-shops do not ship to my place of residence. \\
\hline $\begin{array}{l}\text { Support of small in-store } \\
\text { merchants }\end{array}$ & Mostly I try to support small business owners. \\
\hline \multirow{3}{*}{$\begin{array}{l}\text { Personal contact with } \\
\text { sellers }\end{array}$} & I can consult with the seller the properties of the goods. \\
\hline & $\begin{array}{l}\text { I am an "old school". I like physical contact with the sales staff and their } \\
\text { "how we can advise or serve". }\end{array}$ \\
\hline & I would like to have a dealer for advice. \\
\hline
\end{tabular}

When analysing the results, the findings can be generalized as follows: reasons arising from the specific online environment (prefer to see grocery in person before buying it, distrust e-merchants to choose the best or freshest grocery, hedonic shopping in traditional stores), specifically defined by the characteristics of consumers (the habit of shopping in traditional stores, support of small in-store merchants, physical availability), delivery reasons (faster instore grocery shopping, unwillingness to pay for delivery), reasons caused by inexperience with online purchase of grocery (difficulties to return purchases, special offers in traditional stores, Greater choice in traditional stores), and psychological reasons (A sense of safety in traditional stores, Satisfaction in traditional stores, Personal contact with sellers). A more in-depth analysis of individual respondent responses suggests that respondents often have distorted views about online grocery shopping. This can be due to many factors. The main reason seems to be inexperience with this way of purchasing grocery. Specifically, the inability to read the composition of the product (also possible in the online environment), I would like to have a dealer for advice (also possible in the online environment via "online life chat"), I choose the freshest goods carefully (the usual practice is that sales agents only choose the freshest food), Faster choice in a traditional shop (survey focused on speed of buying offline and online found that online purchasing speed is the same or faster than offline) (Szymanski \& Hise, 2000; Anesbury et al., 2016).

The frequency analysis (Table 5) was performed to determine the impact of individual reasons for not buying grocery online (specified by thematic units). It was found out $43 \%$ of respondents did not buy grocery online because they had preferred to see grocery in person before buying it. Based on the analysis, it is the strongest factor that negatively affects the attitude of customers regarding the purchase of grocery this way. The second most mentioned reason (24.9\% of respondents) is distrust of e-merchants. Respondents are convinced that only they can choose the freshest goods carefully and pick the best goods. Nearly $9 \%$ of respondents believe that buying offline is faster than online grocery shopping. These three reasons affect most customers' attitude not to purchasing grocery online. The remaining reasons together affect only less than a quarter of respondents. 
Table 5. The frequency analysis (source: own research)

\begin{tabular}{|c|l|c|c|}
\hline Code & \multicolumn{1}{|c|}{ Thematic unit } & Frequency & Overall ranking \\
\hline 1 & Prefer to see grocery in person before buying it & 406 & 1. \\
\hline 2 & Distrust e-merchants to choose the best or freshest grocery & 235 & 2. \\
\hline 4 & Faster in-store grocery shopping & 81 & 3. \\
\hline 14 & Personal contact with sellers & 42 & 4. \\
\hline 3 & The habit of shopping in traditional stores & 35 & 5. \\
\hline 6 & Difficulties to return purchases & 31 & 6. \\
\hline 7 & Hedonic shopping in traditional stores & 25 & 7. \\
\hline 5 & Unwillingness to pay for delivery & 23 & 8. \\
\hline 8 & Special offers in traditional stores & 19 & 9. \\
\hline 12 & Physical availability & 17 & 10. \\
\hline 9 & Greater choice in traditional stores & 13 & 11. \\
\hline 10 & A sense of safety in traditional stores & 7 & 12. \\
\hline 11 & Satisfaction in traditional stores & 1 & 13. \\
\hline 13 & Support of small in-store merchants & & 14. \\
\hline
\end{tabular}

For nearly $70 \%$ of respondents, it is important to be able to look at the grocery in person, smell it, see its condition, taste it, assess its durability, packaging damage, condition, freshness; and choose the right goods to meet their requirements. Of course, other reasons resulting from the characteristics of consumers, the delivery process, inexperienced with online grocery purchases and/or psychological factors are also important but compared to those directly related to the online environment, they are not as crucial for e-merchants. For the acceptance of online grocery shopping (penetration of online grocery shopping in the Czech Republic), the most important is the situation when consumers begin to trust retailers that the goods will always be of the best possible quality.

\subsection{Comparison of results from previous studies and our research}

First, we want to compare our research design with reviewed work before we get to the comparison of the results. Our sample (670) is close to the average (752.5) for the studies under investigation. Furthermore, we used induction and deduction jointly and quantified qualitative data. This approach is relatively novel comparing to reviewed studies where deduction approach and quantitative methodology dominate. We surveyed a fairly representative sample of consumers similar to the studies. However, comparing data collection, we mirrored only four where the web-based questionnaire was used.

Not surprisingly, our data shows the main factor behind restraint to purchase is the absence of the possibility to incorporate all senses when buying. Likewise, smell and in some cases hear what product is made of emerges in almost every study about OGS adoption. This renders also a second most frequently mentioned problem in our survey, and it is the trust in retailer to pick the best grocery product for the customer. There is a high perception of the risk of receiving inferior quality groceries (Ramus \& Nielsen, 2005). We see similar 
conclusions in the work of Pechtl (2003) and Hansen (2005a). Perceived limited information accessibility was confirmed by both quantitative and qualitative studies. In this case, the information means signals captured by all the senses.

Further, Seitz et al. (2017) deduced the current habitual buying was convenient and people generally did not strive for change. They stick to the status quo and choose a secure and familiar environment. In our research respondents were simply not seeing the reasons why they should start buying groceries online. We further confirmed the negative perception of delivery payment. Shipping charges were the concern also for customers researched in the recent Driediger and Bhatiasevi (2019) article.

There are also hedonic factors why people love to buy groceries in brick and mortar stores. Geuens et al. (2003) described consumers who desire relaxing experience in stores. The process of picking, tasting and touching the product constitutes a relevant factor in purchase decision making. More studies arrived at identical conclusions about consumers wishing to experience fun and enjoyment while shopping (Ramus \& Nielsen, 2005; Šálková $\&$ Hes, 2015). According to them, there is a fear of a loss of the recreational aspect of grocery shopping. We supported the previous studies since one thematic unit in our results is hedonic shopping motives and its importance for customers when deciding where to buy groceries.

Šarkovská and Chytková (2019) concluded in their qualitative study on Czech respondents that the negative side of online grocery shopping is uniformity of bought groceries. We support their findings since our respondents also mentioned smaller product range and fewer options in online grocery stores. We identified distrust in online shopping as a second most important repellent factor. Similarly, Šálková and Hes (2015) reported this factor to be important for customers when making decision to buy groceries online. Moreover, they concluded Czech shoppers are reluctant to give up control over the selection of goods and to allow strangers to handle their groceries. This trust issue is thus serious mental barrier in consumers mind.

Besides re-confirmation of several important factors which discourage customers to shop groceries online, we found also novel reasons why people hesitated to utilize OGS. Surprisingly, people perceive OGS as slow, compared to traditional in-store shopping. This is mainly due to the time gap between ordering and delivery. Additionally, for some specific situations, the urgency to buy the product immediately make online buying completely unreasonable. In the situation when the customer runs out of milk or bread. However, the issue of speed has to be divided into two categories. First, there is the ordering - delivery time gap which is, with current technology, still shorter in brick and mortar stores. Second, there is the total time required for completing the purchase. Here the online grocery shopping overperform brick and mortar by miles. With an easy thought experiment, we can summarize the activities necessary to buy offline. First, the customer has to go to the shop physically, then he or she has to find and collect what they need. Then there are queues at checkout and distance between the shop and car or public transport. Finally, the customer has to move back home from the shop. Compared with online full-text search, filters, previous shopping lists, easy payment and home delivery, the online is more reliable in saving total shopping time. Yet still, the online shopping is perceived relatively slow.

Further very little research among non-buyers addressed the problem of the return policies. However, the uncertainty of the process and what would happen if the groceries ordered 
online not fitting the expectations causes negative perception about this form of shopping. This is mainly because people generally do not return groceries product since they are responsible for picking the one, they want to buy. So, the concept of returning the product is unfamiliar. Moreover, the complicated process behind returning policies in OGS is also reflected in discouraging attitudes. Non-buyers simply cannot imagine an easy way to submit their complaints easily or return goods effortlessly.

\section{Conclusions}

In general, OGS is rather an evolution than revolution thus we were interested in attitudes and opinions that form disincentive reasons why consumers hesitate to shop groceries online. We reviewed studies where the object of research were actual non-buyers and arrived at several conclusions. There is a difference within customers based on their experience with online grocery shopping and even regular online buyers are dissimilar to only offline buyers in OGS perception. Theory of reasoned action and the following models are very popular in describing reasons deductively why consumers hesitate to shop online. Attitudes toward the behaviour, subjective norms and perceived behavioural control are a validated determinant of OGS intention. Hence, we designed a survey with open questions in the search for new reasons as well as validation of previously researched items. The most mentioned first reason is the preference to see grocery in person before buying it. Then there is distrust in e-tailer ability to pick the best products on offer and habitual convenience and reluctance to change. We also validated hedonic reasons, when customers simply enjoy the experience of shopping. Last but not least the study also shows novel reasons why people hesitate to perform OGS such as relative time consumption, distrust in the easiness of return policy and unwillingness to pay for the delivery.

Based on the results we propose several recommendations which will help to shift consumers attitudes toward OGS. In the case of marketing communication, it is recommended to e-merchant to work with findings of the content analysis and use them in their marketing communication. It is therefore advisable to refer to trained staff who follow the same procedures for completing an order as if they were completing the order for themselves. In marketing communications, it is also advisable to work with the freshness of food, its smell, its appropriate durability, packaging and overall appropriate condition.

In the case of modern technology, there is the possibility to use virtual reality, which can link elements of online and offline shopping. In this way, customers can browse through a virtual store that allows them to physically check the quality and freshness of the product. Researchers have already explored this possibility and found out movement through a VR grocery store could be tolerated by persons with and without vestibular dysfunction (Whitney et al., 2006). However, this possibility is questionable given the high investment costs, as there is no research confirming the increased interest in online grocery shopping after implementing this technology. Based on the overall service perception in our survey the etailer should focus on services which, directly or indirectly, can mitigate the negative attitude of consumers in the case of distrust in the quality choice of goods by the e-tailer and inability to see the grocery in advance. 
To bridge the time gap between the ordering and delivery and reluctance to pay for delivery the click\&collect service could bring enormous value. This system already operates on the Czech market in different sectors (for example in the sale of electronics, fashion, drugstore) and has also been implemented in the area of grocery shopping. Although research suggests that existing customer prefers door to door delivery, click\&collect can be recommended based on the results, which would mitigate the negative effect of the reasons for not purchasing grocery online of potential customers. A significant advantage of this service is the possibility to check the quality and required number of goods directly at the seller point and their easy possible complaint. For established grocery stores, setting up such points of sale is certainly a good choice to complement the services for their customers, unfortunately for purely e-tail companies, setting up such a point can be an unreasonably costly matter.

This study bears some limitations. Due to the IPSOS research company policy, only respondents older than 16 years of age can be recruited as members of their panel. Consequently, younger generation has been neglected in this study. Moreover, with our sampling, we reached the group which will most probably be the easiest to convert to OGS buyers (internet population) however there are also individuals in the population who do not use the internet so often and do not buy online at all. Logically, these people had a lower chance to participate in the survey since we used a web-based questionnaire thus neglecting a large proportion of potential future OGS customers. Besides, we asked open question with qualitative intent so the overall proportion of reasons why non-buyers still do not want to buy groceries online cannot be generalised from this research since there is a possibility that one respondent holds multiple attitudes about online grocery shopping. This leads us to future research possibilities. Using our thematic units from the content analysis quantitatively and measure the incidence of the repelling factors in population would help e-tailers prioritise the actions to help increase the number of people buying groceries online.

\section{Funding}

This research was financially supported by the Student grant competition project SGS/7/2017: "Acceptance of technology from the perspective of marketing tools".

\section{Author contributions}

IPSOS research agency was responsible for data collection through online responding panel. Authors contributed evenly.

\section{Disclosure statement}

Authors declare to have not any competing financial, professional, or personal interests from other parties. 


\section{References}

Anesbury, Z., Nenycz-Thiel, M., Dawes, J., \& Kennedy, R. (2016). How do shoppers behave online? An observational study of online grocery shopping. Journal of Consumer Behaviour, 15(3), 261-270. https://doi.org/10.1002/cb.1566

Andrews, R. L., \& Currim, I. S. (2004). Behavioural differences between consumers attracted to shopping online versus traditional supermarkets: Implications for enterprise design and marketing strategy. International Journal of Internet Marketing and Advertising, 1(1), 38-61. https://doi.org/10.1504/IJIMA.2004.003689

Bryman, A. (2016). Social research methods. Oxford University Press.

Burman, L. E., Reed, W. R. \& Alm, J. (2010). A call for replication studies. Public Finance Review, 39(1), 190-190. https://doi.org/10.1177/1091142110395372

Campo, K., \& Breugelmans, E. (2015). Buying groceries in brick and click stores: Category allocation decisions and the moderating effect of online buying experience. Journal of Interactive Marketing, 31(3), 63-78. https://doi.org/10.1016/j.intmar.2015.04.001

Cook, D. J., Mulrow, C. D., \& Haynes, R. B. (1997). Systematic reviews: Synthesis of best evidence for clinical decisions. Annals of Internal Medicine, 126(5), 376-380. https://doi.org/10.7326/0003-4819-126-5-199703010-00006

Counsell, C. (1997). Formulating questions and locating primary studies for inclusion in systematic reviews. Annals of internal medicine, 127(5), 380-387. https://doi.org/10.7326/0003-4819-127-5-199709010-00008

Czech Statistical Office. (2019a). Czech Republic in numbers 2018 - population. Retrieved August 13, 2019, from https://www.czso.cz/documents/10180/91917716/1300641901.pdf/b6fa7e0f-25d1-44c29d24-f29b42f41ffb?version $=1.0$

Czech Statistical Office. (2019b). Czech Republic in numbers 2018 - education. Retrieved August 13, 2019, from https://www.czso.cz/documents/10180/74413697/32020318c22.pdf/737a5249-7b3b418f-a45e-a0c3abaf61bd?version $=1.2$

Danaher, P. J., Wilson, I. W., \& Davis, R. A. (2004). A comparison of online and offline consumer brand loyalty. Marketing Science, 22(4), 461-476. https://doi.org/10.1287/mksc.22.4.461.24907

Degeratu, A., Rangaswamy, A., \& Wu, J. (2000). Consumer choice behavior in online and traditional supermarkets: The effects of brand name, price and other search attributes. International Journal of Research in Marketing, 17(1), 55-78. https://doi.org/10.1016/S0167-8116(00)00005-7

Denyer, D., \& Tranfield, D. (2011). Producing a systematic review. In D. Bouchmann, A. Bryman (Eds.), The SAGE handbook of organizational research methods. SAGE.

Driediger, F., \& Bhatiasevi, V. (2019). Online grocery shopping in Thailand: Consumer acceptance and usage behavior. Journal of Retailing and Consumer Services, 48(3), 224-237. https://doi.org/10.1016/j.jretconser.2019.02.005

Easley, R. W., Madden, C. S., \& Dunn, M. G. (2000). Conducting marketing science. Journal of Business Research, 48(1), 83-92. https://doi.org/10.1016/S0148-2963(98)00079-4

Eurostat. (2019a). E-commerce statistics for individuals. Retrieved August 11, 2019, from https:// ec.europa.eu/eurostat/statistics-explained/index.php/E-commerce_statistics_for_individuals

Eurostat. (2019b). Internet purchases by individuals. Retrieved August 11, 2019, from https://ec.europa. eu/eurostat/web/products-datasets/product?code=isoc_ec_ibuy

Evanschitzky, H., Baumgarth, C., Hubbard, R., \& Armstrong, J. S. (2007). Replication research's disturbing trend. Journal of Business Research, 60(4), 411-415. https://doi.org/10.1016/j.jbusres.2006.12.003

Fink, A. (2009). How to conduct surveys: A step-by-step guide. Sage Publications Ltd. 
Fisch, C., \& Block, J. (2018). Six tips for your (systematic) literature review in business and management research. Management Review Quarterly, 68(2), 103-106.

https://doi.org/10.1007/s11301-018-0142-x

Galvez-Cruz, D., \& Renaud, K. V. (2006). What e-grocery customers really want: Personalised personalisation. Fourth Latin American Web Congress, 18(6), 109-112.

https://doi.org/10.1109/LA-WEB.2006.38

Garg, A. X., Hackam, D., \& Tonelli, M. (2008). Systematic review and meta-analysis: When one study is just not enough. Clinical Journal of the American Society of Nephrology: CJASN, 3(1), 253-260. https://doi.org/10.2215/CJN.01430307

Geuens, M., Brengman, M., \& S'Jegers, R. (2003). Food retailing, now and in the future. A consumer perspective. Journal of Retailing and Consumer Services, 10(4), 241-251.

https://doi.org/10.1016/S0969-6989(02)00017-6

Hand, C., Dall'Olmo Riley, F., Harris, P., Singh, J., \& Rettie, R. (2009). Online grocery shopping: The influence of situational factors. European Journal of Marketing, 43(9/10), 1205-1219. https://doi.org/10.1108/03090560910976447

Hansen, T., Møller Jensen, J., \& Stubbe Solgaard, H. (2004). Predicting online grocery buying intention: a comparison of the theory of reasoned action and the theory of planned behavior. International Journal of Information Management, 24(6), 539-550. https://doi.org/10.1016/j.ijinfomgt.2004.08.004

Hansen, T. (2005a). Consumer adoption of online grocery buying: a discriminant analysis. International Journal of Consumer Studies, 33(2), 101-121. https://doi.org/10.1108/09590550510581449

Hansen, T. (2005b). Understanding consumer online grocery behavior: Results from a Swedish study. Journal of Euromarketing, 14(3), 31-58. https://doi.org/10.1300/J037v14n03_03

Hansen, T. (2008). Consumer values, the theory of planned behaviour and online grocery shopping. International Journal of Consumer Studies, 32(2), 128-137.

https://doi.org/10.1111/j.1470-6431.2007.00655.x

Hubbard, R., \& Armstrong, J. S. (1994). Replications and extensions in marketing: Rarely published but quite contrary. International Journal of Research in Marketing, 11(3), 233-248. https://doi.org/10.1016/0167-8116(94)90003-5

Huyghe, E., Verstraeten, J., Geuens, M., \& Van Kerckhove, A. (2016). Clicks as a healthy alternative to bricks: How online grocery shopping reduces vice purchases. Journal of Marketing Research, 54(1), 65. https://doi.org/10.1509/jmr.14.0490

Kestenbaum, R. (2017, January 16). Why online grocers are so unsuccessful and what Amazon is doing about it. Forbes. https://www.forbes.com/sites/richardkestenbaum/2017/01/16/why-online-grocersare-so-unsuccessful-and-what-amazon-is-doing-about-it/

Kozel, R., Hawrysz, L., Vilamová, Š., \& Hys, K. (2017). Mystery e-mail/website customer service. A case study of retail companies. Scientific Papers of the University of Pardubice, Series D: Faculty of Economics and Administration, 24(40), 95-107.

Kunešová, H., \& Eger, L. (2017). Evaluation and comparison of B2C e-commerce intensity in EU member states. E+M Ekonomie a Management, 20(4), 151-167.

https://doi.org/10.15240/tul/001/2017-4-011

MacInnis, D. J., Morwitz, V. G., Botti, S., Hoffman, D. L., Kozinets, R.V., Lehmann, D. R., Lynch, J. G. \& Pechmann, C. (2020). Creating boundary-breaking, marketing-relevant consumer research. Journal of Marketing, 84(2), 1-23. https://doi.org/10.1177/0022242919889876

Martín, J. C., Pagliara, F., \& Román, C. (2019). The research topics on e-grocery: trends and existing gaps. Sustainability, 11(2), 321. https://doi.org/10.3390/su11020321

Pechtl, H. (2003). Adoption of online shopping by German grocery shoppers. The International Review of Retail, Distribution and Consumer Research, 13(2), 145-159.

https://doi.org/10.1080/0959396032000099088 
Potomková, J. (2005). Význam systematických přehledů pro medicínu založenou na důkazu. Pediatrie pro Praxi, 7(2), 105-106. https://www.pediatriepropraxi.cz/pdfs/ped/2004/02/17.pdf

Ramus, K., \& Nielsen, A. N. (2005). Online grocery retailing: What do consumers think? Internet Research, 15(3), 335-352. https://doi.org/10.1108/10662240510602726

Šálková, D., \& Hes, A. (2015). Internet food sales service - barriers to the development of online grocery shopping in the Czech Republic. In J. Matus \& D. Petranova (Eds.), Marketing identity: digital life (Part II, pp. 247-255). University of Ss Cyril and Methodius in Trnava.

Šarkovská, K., \& Chytková, Z. (2019). Benefits and pitfalls of online grocery shopping as perceived by the consumers: Evidence from the Czech Republic. Privredna Kretanja i Ekonomska Politika, 14(3), 35-58. https://doi.org/10.15179/pkiep.27.2.2

Saunders, A., Lewis, P., \& Thornhill, A. (2016). Research methods for business students. Pearson Education Ltd.

Seitz, C., Pokrivčák, J., Tóth, M., \& Plevný, M. (2017). Online grocery retailing in Germany: an explorative analysis. Journal of Business Economics and Management, 18(6), 1243-1263. https://doi.org/10.3846/16111699.2017.1410218

Simová, J., \& Cinkánová, L. (2016). Attributes contributing to perceived customer value in the Czech clothing on-line shopping. E\&M Ekonomie a Management, 19(3), 195-206. https://doi.org/10.15240/tul/001/2016-3-013

Soopramanien, D. (2011). Conflicting attitudes and scepticism towards online shopping: The role of experience. International Journal of Consumer Studies, 35(3), 338-347. https://doi.org/10.1111/j.1470-6431.2010.00945.x

Suchánek, P. (2010). The fundamentals of a prosperous e-shop in connection to search engine optimization. E\&M Ekonomie a Management, 13(2), 92-103.

Szymanski, D. M., \& Hise, R. T. (2000). E-satisfaction: An initial examination. Journal of Retailing, 76(3), 309-322. https://doi.org/10.1016/S0022-4359(00)00035-X

Tahal, R. (2015). Základní metody sbèru primárních dat v marketingovém výzkumu. C. H. Beck.

Tranfield, D., Denyer, D., \& Smart, P. (2003). Towards a methodology for developing evidence-informed management knowledge by means of systematic review. British Journal of Management, 14(3), 207222. https://doi.org/10.1111/1467-8551.00375

Uman, L. S. (2011). Systematic reviews and meta-analyses. Journal of the Canadian Academy of Child and Adolescent Psychiatry, 20(1), 57-59.

Verhoef, P. C., \& Langerak, F. (2001). Possible determinants of consumers' adoption of electronic grocery shopping in the Netherlands. Journal of Retailing and Consumer Services, 8(5), 275-285. https://doi.org/10.1016/S0969-6989(00)00033-3

Wang, O., \& Somogyi, S. (2018). Consumer adoption of online food shopping in China. British Food Journal, 120(12), 2868-2884. https://doi.org/10.1108/BFJ-03-2018-0139

White, A., \& Schmidt, K. (2005). Systematic literature reviews. Complementary Therapies in Medicine, 13(1), 54-60. https://doi.org/10.1016/j.ctim.2004.12.003

Whitney, S. L., Sparto, P. J., Hodges, L. F., Babu, S. V., Furman, J. M., \& Redfern, M. S. (2006). Responses to a virtual reality grocery store in persons with and without vestibular dysfunction. Cyberpsychology \& Behaviour, 9(2), 152-156. https://doi.org/10.1089/cpb.2006.9.152

Young, J. (2019, January 21). Global ecommerce sales grow 18\% in 2018. Digital Commerce 360. https://www.digitalcommerce360.com/2019/01/21/global-ecommerce-sales-grow-18-in-2018/ 